\title{
Environmental concentrations of Roundup in combination with chlorpromazine or heating causes biochemical disturbances in the bivalve mollusc Unio tumidus
}

\author{
Vira Khoma ${ }^{1}$ - Viktoria Martinyuk ${ }^{1} \cdot$ Tetyana Matskiv $^{1,2} \cdot$ Lesya Gnatyshyna $^{1,2} \cdot$ Vitaliy Baranovsky $^{1} \cdot$ Mykola Gladiuk $^{1}$. \\ Brigita Gylyte $^{3} \cdot$ Levonas Manusadžianas $^{3} \cdot$ Oksana Stoliar $^{1}$ (i)
}

Received: 25 June 2021 / Accepted: 23 September 2021 / Published online: 3 October 2021

(C) The Author(s), under exclusive licence to Springer-Verlag GmbH Germany, part of Springer Nature 2021

\begin{abstract}
Bivalve molluscs represent the most recognized bioindicators of freshwater pollution. However, their ability to indicate specific xenobiotics in complex exposures is unclear. In this study, we aimed to track the particular effects of the pesticide Roundup (Rnd) and the antipsychotic drug chlorpromazine (Cpz) on the mussel Unio tumidus at the simpler environmentally relevant models. We treated the mussels by Rnd $\left(17 \mu \mathrm{g} \mathrm{L}^{-1}\right), \mathrm{Cpz}\left(18 \mu \mathrm{g} \mathrm{L}{ }^{-1}\right)$, the mixture of Rnd and $\mathrm{Cpz}$ at $18^{\circ} \mathrm{C}(\mathrm{RndCpz})$, and Rnd at $25^{\circ} \mathrm{C}$ (RndT) and examined their digestive glands after 14 days of exposure. We analyzed total antioxidant capacity, glutathione (GSH\&GSSG) and protein carbonyls levels, total and Zn-related concentrations of metallothioneins (MT and Zn-MT, respectively), the activities of CYP450-related EROD, glutathione $S$-transferase, cholinesterase, caspase-3, citrate synthase (CS), lysosomal membrane integrity (NRR), and Zn level in the tissue. Shared responses were indicated as the increase of the antioxidant, Zn-MT, and EROD levels, whereas the changes of Zn concentration, NRR, and caspase-3 activity were most diverse compared to control. According to discriminant analysis, complex exposures abolished the individual response traits and intensified the harmful effects that caused a decrease in the Zn level in the RndCpz- and RndT-groups and the loss of lysosomal integrity in the RndT-group. We concluded that multi-marker expertise with the application of integrated indices had benefits when evaluating the effects of complex exposures.
\end{abstract}

Keywords Bivalve mollusc $\cdot$ Complex pollution $\cdot$ Antioxidants $\cdot$ Zinc $\cdot$ Cytotoxicity

Responsible Editor: Bruno Nunes

\section{Highlights}

1. Exposure of bivalves to Roundup and heating or chlorpromazine in nanomolar concentrations.

2. Shared responses of antioxidant and metabolic activation.

3. Roundup at heating decreased tissue $\mathrm{Zn}$ and lysosome integrity indicating damage.

4. Specific responses to Roundup and chlorpromazine were abolished in their joint exposure.

\section{Oksana Stoliar}

Oksana.Stolyar@tnpu.edu.ua

1 Ternopil Volodymyr Hnatiuk National Pedagogical University, Ternopil, Ukraine

2 I. Horbachevsky Ternopil National Medical University, Ternopil, Ukraine

3 Nature Research Centre, Vilnius, Lithuania

\section{Introduction}

Bivalve molluscs are well-known bioindicator species of surface water chemical pollution and climate change. Various biomarkers have been utilized for characterizing the health status of these organisms affected by abiotic stresses (Louis et al. 2020). However, specific responses of molluscs to certain xenobiotics have been examined generally in the exposures to single substances at high concentrations (Giménez and Nunes 2019), which are hardly expected in the environment unless pollutants are released accidentally. The demand for "evidence-based ecotoxicology" (Martin et al. 2019) includes the elaboration of environmentally realistic models for risk assessment. In this study, we aimed to track the particular effects of the pesticide Roundup (Rnd) and the antipsychotic drug chlorpromazine (Cpz) on the mussel Unio tumidus at the simpler environmentally relevant models (Hong et al. 2017). 
The substances selected for the study are common aquatic pollutants. As a commercial form of glyphosate, Rnd is one of the most frequently used pesticides worldwide (Matozzo et al. 2020). The levels of glyphosate in freshwaters may reach hundreds of $\mu \mathrm{g} \mathrm{L}^{-1}$. This polar, highly water-soluble substance having rather high persistence inputs surface waters due to field application (Bonansea et al. 2018). In Argentina, for example, water samples demonstrate the presence of glyphosate at a maximum of $125 \mu \mathrm{g} \mathrm{L}^{-1}$, while the limit set by the Argentinean Environmental Water Quality Guidelines to protect freshwater aquatic life is $240 \mu \mathrm{g} \mathrm{L}^{-1}$ (Bonansea et al. 2018). The glyphosate concentration in French surface waters varies from $0.12 \pm 0.02$ to $0.32 \pm 0.05 \mu \mathrm{g} \mathrm{L}^{-1}$ but can as well reach up to $164 \mathrm{Mg} \mathrm{L}^{-1}$ (Carles et al. 2019). Besides, the highest concentration of glyphosate in the small rivers of Germany was $0.59 \mu \mathrm{g} \mathrm{L}^{-1}$ only (Skark et al. 1998) attesting the rise of its concentrations in the freshwater nowadays.

One possible reason behind glyphosate toxicity is suggested to be its chelating properties towards divalent metal ions that alter the bioavailability of nutrients in plants and soil microorganisms (Mertens et al. 2018). Therefore, it can be expected that it has an impact on metal metabolism in nontargeted species. However, the signs of its toxicity for aquatic species, mainly marine invertebrates, are mostly reported as the oxidative stress responses, endocrine, immune, and histological alterations at as low as $0.1-100 \mu \mathrm{g} \mathrm{L}^{-1}$ concentrations in the in vitro, ex vivo, acute, and subchronic in vivo exposures (El Haj et al. 2019; Khoma et al. 2020, 2021; Matozzo et al. 2020 and references therein). Studies of complex exposures of aquatic species that include glyphosate are scant, and those available are mainly devoted to compositions with copper (Hansen and Roslev 2016; Liu et al. 2019).

The other chemical studied here, $\mathrm{Cpz}$, is the firstgeneration neuroleptic medication known as dopamine $\mathrm{D}_{2}$ receptor antagonist ( $\mathrm{Li}$ et al. 2016). The $\mathrm{Cpz}$ investigation has been motivated by its popularity till nowadays. Among 197 substances analyzed in hospital wastewater, $\mathrm{Cpz}$ is one of the 15 particularly hazardous chemicals present at high concentrations ( $\mathrm{mg} \mathrm{L}^{-1}$ ) (Frédéric and Yves 2014). The persistence of $\mathrm{Cpz}$ in river water and strong adsorption on sediments have also been reported (Jiménez et al. 2016). The mean Cpz concentration in sewage treatment plant effluents amounts to $11.3 \mathrm{ng} \mathrm{L}^{-1}$ in Sweden (Baresel et al. 2015). Recently, it has been reported that Cpz has an antiviral activity in vitro against the influenza virus, HIV. It is listed among "the most promising molecules for inhibiting coronaviruses in human cells" as well (Stip et al. 2020). Consequently, its input into the water runoff is expected to be enhanced. The biological effects of $\mathrm{Cpz}$ are associated with calcium homeostasis (Xu et al. 2010) and manganese toxicity (Nelson et al. 2018). The drug is known to interact with the cell membrane dynamin and block the clathrindependent endocytosis essential for the entry of coronavirus into the host cell (Plaze et al. 2020). Therefore, its biochemical effects are expected to be related to its involvement in metal uptake and metabolism. High toxic pressure of $\mathrm{Cpz}$ has been confirmed by the fish plasma model in the concentration of $36 \mathrm{ng} \mathrm{L}^{-1}$ (Miller et al. 2019). However, the results of acute and chronic exposures of cladoceran Daphnia magna (Oliveira et al. 2015; Alkimin et al. 2020) and mussels Mytilus galloprovincialis (Yang et al. 2011) to $\mathrm{Cpz}$ in a range from 0.01 to $250 \mu \mathrm{g} \mathrm{L} \mathrm{L}^{-1}$ hardly show the changes in terms of physiological and biochemical parameters. To the best of our knowledge, any information concerning the interaction of $\mathrm{Cpz}$ with other aquatic pollutants, particularly the disruptors of metal homeostasis, has not been reported so far.

To reflect the hazard of chemical pollution on the aquatic life, the input of the abnormal temperatures as an important and even crucial driver should also be taken into consideration. The frequency, intensity, and duration of extreme heat events are projected to continue to increase through the twenty-first century, with all regions expected to experience unprecedented temperatures (Ebi et al. 2021). Elevated temperature is known to exacerbate the toxicity or distort effects in bivalve molluscs induced by xenobiotics such as mixtures containing Rnd (Negri et al. 2013; Patra et al. 2015; Payton et al. 2016; Louis et al. 2020; Khoma et al. 2021). Metal metabolism and toxicity depend on thermal stress, and lysosomal biomarkers reflect this impact in molluscs (Izagirre et al. 2014). However, the limits of adaptive responses to the combined pollution of chemicals simultaneously with temperature extremes are not adequately understood (Louis et al. 2020).

Based on our own experience (Khoma et al. 2020, 2021), and with the aim of ensuring environmentally relevant limits of impact, we utilized low Rnd concentration (Maycock et al. 2012). It was two times lower than the concentration of Rnd that caused distortion of metal metabolism and oxidative stress in U. tumidus (Khoma et al. 2021). Similarly, we chose $\mathrm{Cpz}$ concentration that caused minor physiological effects in aquatic animals (Oliveira et al. 2015). We selected the two temperatures of exposure $\left(18^{\circ}\right.$ and $\left.25^{\circ} \mathrm{C}\right)$ for their relevance within the range of water temperatures in the sampling area at the Dniester River basin (see https://ukr.seatemperature.net/seas-andrivers/reka-dnestr).

Due to the suspected ability of both substances to affect metal metabolism, we focused on the cellular thiols involved in the zinc $(\mathrm{Zn})$ intracellular distribution, metallothioneins, and glutathione (GSH/GSSG). Also, we evaluated oxidative stress, biotransformation and metabolic activities, and the signs of cytotoxicity. We applied an integrative analysis to compare the responses in various experimental groups. 


\section{Materials and methods}

The methodology used is given in detail in Supplementary information (SI 1).

\section{Chemicals}

All reagents were of the reagent grade or higher (SI1 Appendix). They were obtained from Sigma-Aldrich (USA) or the Synbias (Ukraine). Rnd formulation was Roundup MAX, Monsanto, USA, and Cpz was of pharmaceutical grade, AMINAZINUM, Pat "Halychfarm," ATX N05A A01.

\section{Experimental groups}

Adult bivalve molluscs Unio tumidus Philipson, 1788 (Unionidae) ( $\sim 6$ years old, $\sim 8.5 \mathrm{~cm}$ length, and $60-70 \mathrm{~g}$ weight) were collected in a river site assumed to be a reference (Gnatyshyna et al. 2020). Specimens were transported to the laboratory and preacclimated to the laboratory conditions for up to 7 days after the capture in the aerated, dechlorinated, softened tap water and fed $500 \mathrm{mg}$ of Tropical SuperVit Basic contained beta-1.3/1.6-glucan twice a week. After that, molluscs were distributed randomly to five groups. The first group was exposed to the aquarium water only and was considered control (C). The Rnd- and RndT-groups were exposed to Rnd MAX (17 $\mu \mathrm{g} \mathrm{L}^{-1}$, corresponding to $6.1 \mu \mathrm{g} \mathrm{L}^{-1}$ or $36 \mathrm{nM}$ of glyphosate) at the temperatures $18^{\circ} \mathrm{C}$ and $25^{\circ} \mathrm{C}$, respectively. The Cpz-group was exposed to $18.0 \mu \mathrm{g} \mathrm{L}^{-1}$ or $56 \mathrm{nM}$ of $\mathrm{Cpz}$ and the RndCpz-group to a mixture of Rnd and $\mathrm{Cpz}$ at $18^{\circ} \mathrm{C}$. The duration of exposure was 14 days. Two replicates per group were used ( 25 specimens per $25 \mathrm{~L}$ tank). Stock solutions of $1.7 \mathrm{~g} \mathrm{~L}^{-1}$ of Rnd MAX and $6.1 \mathrm{~g} \mathrm{~L}^{-1}$ of $\mathrm{Cpz}$ were prepared by diluting the commercial formulations in distilled water. The temperature in the RndT-group was increased gradually during $24 \mathrm{~h}$. Water was changed and chemicals replenished every 2 days. Throughout the experiment, molluscs were fed with the same regularity. No mortality was detected during the experimental exposures.

Utilized concentration of Rnd corresponded to 0.2 longterm PNEC for freshwater organisms (rounded) (Maycock et al. 2012). Concentration of $\mathrm{Cpz}$ corresponded to the level approximately equal to the concentration detected in sewage treatment plant effluents (Baresel et al. 2015) multiplied by 1000 and to $1 / 100$ of EC50 value $\left(1.805 \mathrm{mg} \mathrm{L}^{-1}\right)$ for D. magna (Oliveira et al. 2015). The duration of exposure and temperature range was based on the previous experience (Khoma et al. 2020) and relevance to the range of water temperatures in the sampling area (https://ukr.seatemperature.net/ seas-and-rivers/reka-dnestr).

After exposures, molluscs were dissected on ice, and sex was determined. Only male specimens were utilized. For all experiments, the digestive gland was used. For lisosomal membrane stability and cholinesterase activity, the samples of tissues were utilized immediately. For all biochemical traits except concentrations of metals in metallothioneins, the samples were prepared from eight individual molluscs in each experimental group. For all analyses except metallothioneins and caspase-3, tissues were homogenized $(10 \% \mathrm{w} / \mathrm{v})$ in $0.1 \mathrm{M}$ phosphate buffer, $\mathrm{pH} 7.4$, containing $100 \mathrm{mM} \mathrm{KCl}$ and $1 \mathrm{mM}$ EDTA, as well as $0.1 \mathrm{mM}$ phenylmethylsulfonyl fluoride (PMSF) for proteolysis inhibition. Homogenates were centrifuged at $6000 \mathrm{~g}$ for $10 \mathrm{~min}$, and the resulting supernatant was kept at $-40{ }^{\circ} \mathrm{C}$. For the analysis of cholinesterase, the $10 \% \mathrm{w} / \mathrm{v}$ homogenate was prepared in the same buffer without PMSF. The protein concentration was analyzed in the $6000 \mathrm{~g}$ supernatant according to the method of Lowry et al. (1951), using bovine serum albumin as the protein standard.

\section{Assays for metallothionein and glutathione}

Concentration of metallothioneins protein (MTSH) was assessed using 5,5'-dithio-bis(2-nitrobenzoic acid) (DTNB) reduction method after the ethanol/chloroform extraction from tissue 1:3 w/v homogenate in $20 \mathrm{mM}$ Tris-sucrose buffer with $0.1 \%$ B-mercaptoethanol, $0.5 \mathrm{mM}$ PMSF, and $6 \mu \mathrm{M}$ leupeptin (Viarengo et al. 1997). The concentration of MT was expressed in $\mu \mathrm{g} \mathrm{g}^{-1}$ tissue FW.

For the evaluation of $\mathrm{Zn}$ concentration in metallothioneins (Zn-MT), $70 \mathrm{mg}$ of tissue per individual (to a total of $350 \mathrm{mg}$ from five specimens in the group) was combined. Two replicates for each group were accomplished. The samples were homogenized in $10 \mathrm{mM}$ Tris-HCl buffer, $\mathrm{pH} 8.0$ containing $10 \mathrm{mM} \beta$-mercaptoethanol and $0.1 \mathrm{mM}$ PMSF, and subjected to the isolation of thermostable supernatant. The MTcontained fractions were isolated from the supernatant by size-exclusion chromatography on Sephadex G-50 with necessary adjustments needed to avoid their oxidation (Roesijadi and Fowler 1991). Low-weight (approximately $7 \mathrm{kDa}$ ) fractions with high absorbance at $254 \mathrm{~nm}$ and high $\mathrm{D}_{254} / \mathrm{D}_{280}$ density ratio were identified as putative MT-containing peak and pooled (to the total of $10 \mathrm{~mL}$ ) for the $\mathrm{Zn}$ determination.

Total glutathione and oxidized glutathione (GSSG) concentrations were quantified by the glutathione reductase recycling assay (Griffith 1980) in the protein-free extract of homogenate using DTNB. Concentration was expressed as $\mathrm{nmol} \mathrm{g}{ }^{-1} \mathrm{FW}$. The concentration of the reduced glutathione (GSH) was calculated as the difference between the total glutathione and GSSG concentrations. The redox index of glutathione (RI GSH) as the ratio of concentrations GSH/GSSG was calculated.

\section{Oxidative stress and toxicity assays}

Total antioxidant capacity (TAC) was determined as ABTS radical scavenging activity (Re et al. 1999). $\mathrm{ABTS}^{\circ+}$ radical 
cations $(\mathrm{ABTS} *$ ) were generated from 2,2'-azino-di-[3ethylbenzthiazoline sulfonate] (ABTS) by potassium persulfate. The ascorbic acid was used as the reference compound. The reduction in absorbance of ABTS* solution was recorded at $734 \mathrm{~nm}$. The result was compared with control (only ABTS* solution).

Protein carbonyls (PC) were determined as an index of protein oxidation in the sediment of $10 \% \mathrm{w} / \mathrm{v}$ homogenate in sulfosalicylic acid after its centrifugation by reaction with 2,4dinitrophenylhydrazine (DNPH) (Reznick and Packer 1994). The concentration of carbonyls was expressed in nmol PC per g FW.

Cholinesterase (ChE, EC 3.1.1.7) activity was determined in the homogenate according to the colorimetric method of Ellman et al. (1961) at $25^{\circ} \mathrm{C}$. Acetylcholine iodide (ATCh) was used with DTNB as the thiol indicator. Enzyme activity was referred to the protein content.

Lysosomal membrane integrity was determined by neutral red retention (NRR) test based on the lysosome ability to concentrate the dye as it was described in El Haj et al. (2019). The tissue samples (30 mg) were incubated for $2 \mathrm{~h}$ with a saline solution containing NR, washed and fixed in formaldehyde $\left(0.5 \%\right.$ in $\left.1 \% \mathrm{CaCl}_{2}\right)$. After fixation, the formaldehyde-impregnated tissue fragments were removed and frozen (up to one week). Dye was extracted in acid alcohol (1\% acetic acid in 50\% ethyl alcohol) and analyzed spectrophotometrically at $550 \mathrm{~nm}$.

The ability of exposures to induce cytochrome P450 (CYP450) activity was quantified as 7-ethoxyresorufin $O$ deethylase (EROD) activity in the supernatant of $10 \% \mathrm{w} / \mathrm{v}$ homogenate by measuring the formation of resorufin at $572 \mathrm{~nm}$ (Klotz et al. 1984). The reaction was initiated by the addition of $0.5 \mathrm{mM}$ NADPH. EROD activity was calculated using a molar extinction coefficient of $73.210^{3} \mathrm{M}^{-1} \cdot \mathrm{cm}^{-1}$ and referred to the soluble protein concentration.

Glutathione S-transferase (GST, EC 2.5.1.18) activity was assayed using GSH and 1-chloro-2,4-dinitrobenzene (CDBN) as the substrate (Habig et al. 1974). The GST activity was expressed in nmol $\mathrm{min}^{-1} \cdot \mathrm{mg}^{-1}$ soluble protein.

Caspase-3 (EC:3.4.22.56) activity as the marker of apoptosis was assayed colorimetrically in $25 \% \mathrm{w} / \mathrm{v}$ homogenate of digestive gland tissue based on the hydrolysis of peptide acetyl-Asp-Glu-Val-Asp p-nitroanilide (Ac-DEVD-pNA) by caspase- 3 that produces a colored product $\mathrm{p}$-nitroaniline (pNA). The pNA was detected at $405 \mathrm{~nm}\left(\varepsilon_{\mathrm{mM}}=10.5\right.$ $\mathrm{mM}^{-1} \cdot \mathrm{cm}^{-1}$ ) (Du et al. 1997). The activity of caspase-3 was expressed in nmol pNA min ${ }^{-1} \mathrm{mg}^{-1}$ of soluble protein.

Citrate synthase (CS, EC 2.3.3.1) activity was measured in the $10 \% \mathrm{w} / \mathrm{v}$ homogenate of the digestive gland according to Flynn et al. (2015) as the maximum rate of increase in absorbance at $412 \mathrm{~nm}$, caused by the production of a coenzyme ASH and monitored by DNTB. CS enzyme activity was calculated by subtracting the background activity (negative control) from the CS enzyme activity (positive reaction) for each sample and quantified using the molar extinction coefficient of $\operatorname{DTNB}\left(14,150 \cdot \mathrm{M}^{-1} \mathrm{~cm}^{-1}\right)$.

\section{Zinc concentration in the tissue and metallothioneins}

The concentration of $\mathrm{Zn}$ was measured in the digestive gland tissue (Zn-t) and the pooled MT-containing eluate (Zn-MT) received by chromatography utilizing the reaction of the complexation of $\mathrm{Zn}$ (II) with 2-(5-bromo-2-pyridylazo)-5-[N-propyl-N-(3-sulfopropyl) amino]phenol disodium salt dihydrate (5-Br-PAPS) (Wang et al. 2018). The samples were dried at $105{ }^{\circ} \mathrm{C}$ for $24 \mathrm{~h}$ and then digested with $\mathrm{HNO}_{3}$. The received ash was dissolved in $1 \%$ trichloroacetic acid, and then $36 \mathrm{nM}$ 5 -Br-PAPS (final concentration) in $200 \mathrm{mM}$ bicarbonate buffer ( $\mathrm{pH}$ 8.0) was added. The mixture was incubated for $30 \mathrm{~min}$ at $20^{\circ} \mathrm{C}$. Zn concentration was evaluated from the absorbance of the metal-5-Br-PAPS complex at $560 \mathrm{~nm}$. Fe ions were masked with citric acid, and $\mathrm{Cu}$ ions were masked with salicylaldoxime, deferoxamine, and sodium citrate. The detection limit was $0.1 \mu \mathrm{g} \cdot \mathrm{g}^{-1} \mathrm{FW}$. The reliability of the $\mathrm{Zn}$ measurements was assessed by analyzing ERM-CE 278-certified reference material; metal recovery was between 90 and $110 \%$. Quality control was performed by the method of standard addition. Metal concentration in the tissue and MTs was expressed as $\mu \mathrm{g} \cdot \mathrm{g}^{-1} \mathrm{FW}$.

\section{Statistical analysis}

Results were expressed as mean \pm standard deviation. Metal in MTs analysis was repeated in four samples for each of two independent combined from five individuals replicates in a group, resulting in $n=8$ for each group. For all other traits, the sample size was eight from eight individuals. Shapiro-Wilk test was used for the assessment of normality. Data were analyzed with parametric Student's $t$ test significant at $P<0.05$. Principal component analysis (PCA) was performed to assess the relationship between measured parameters utilizing the rotation method varimax. The adequacy of data was evaluated based on the value of the KMO and Bartlett's test of sphericity. Canonical discriminant analysis was utilized for the separation of the exposed groups. A two-way factorial ANOVA was used to determine the statistical significance of the differences between Rnd-, Cpz-, and RndCpz-groups and the individual biochemical variables among exposures to Rnd and chlorpromazine (significant at $P<0.05$ ). The IBM SPSS Statistics version 26 software for Windows was used for calculations. Correlation was significant at $P<0.05$ level $(r>0.304)$ and $P<0.01(r>$ 0.393 ) (2-tailed), $n=40$.

Integrated biomarker index (IBR) elaborated by Beliaeff and Burgeot (2002) was calculated for 
biomarkers (totally 14). The indices of CAP, EROD, GST, protein carbonyls (PC), GSH, GSSG, RI GSH, metallothionein concentration (MTSH), lysosomal integrity (NRR), caspase-3 activity (Cas-3), cholinesterase activity $(\mathrm{ChE})$, citrate synthase (CS), Zn-metallothionein (ZnMT), and Zn-total (Zn-t) were used for the computation of data. The standardization of data was achieved by $\mathrm{Xi}$ calculation: $\mathrm{Xi}=(\mathrm{Mi}-\mathrm{Mt}) / \mathrm{SDi}$. For $\mathrm{Ai}$ calculation, the computation of data was made as to the Xe-Xc, assuming that the changes of the value in each exposed group (Xe) in relation to control $(\mathrm{Xc})$ are corresponding to the stress or toxicity responses and the value of standardized marker $\mathrm{Xc}$ was adjusted to zero. IBR value for each group was calculated as $[(\mathrm{A} 1 \times \mathrm{A} 2)+(\mathrm{A} 2 \times \mathrm{A} 3)+\ldots(\mathrm{An} \times \mathrm{A} 1)] / 2$. Since the value of IBR is dependent on the number of markers, the termed IBR value was given as IBR/n with $n=14$.

\section{Results}

\section{Cellular soluble thiols and zinc accumulation in the digestive gland}

The level of GSH increased in all exposed groups except Rndgroup, particularly, by 1.8 times, in the RndCpz-group. In the latter group, the level of GSSG also increased. As a result, the RI GSH increased compared to the control condition in all exposed groups except the Rnd-group by 36.0-48.8\% (Fig. 1a-c). MT concentration increased by 33.6-57.7\% in all Rnd-contained exposures, mostly in the RndT-group, whereas $\mathrm{Cpz}$ did not change the level of MT (Fig. 1d). Zn-t concentration decreased in the RndT- and Cpz-groups compared to control value by $15.5 \%$ and $24.3 \%$, respectively, whereas the level of Zn-MT increased in all groups, particularly by $\sim 53 \%$ in the RndT- and Cpz-groups (Fig. 1e and f).
Fig. 1 Concentrations of soluble thiols and $\mathrm{Zn}$ in the digestive gland of $U$. tumidus exposed to Rnd (Rnd), Rnd and heating (RndT), Rnd and chlorpromazine (RndCpz), and chlorpromazine (Cpz) during 14 days. a GSH; b GSSG; c RI GSH; d metallothionein (MT);e $\mathrm{Zn}$ in the tissue ( $\mathrm{Zn}$ $\mathrm{t}$ ); and $\mathbf{f} \mathrm{Zn}$ in metallothioneins (Zn-MT). Data are presented as means \pm standard deviations $(n=$ 8). Different letters above the columns indicate significantly different values $(P<0.05)$

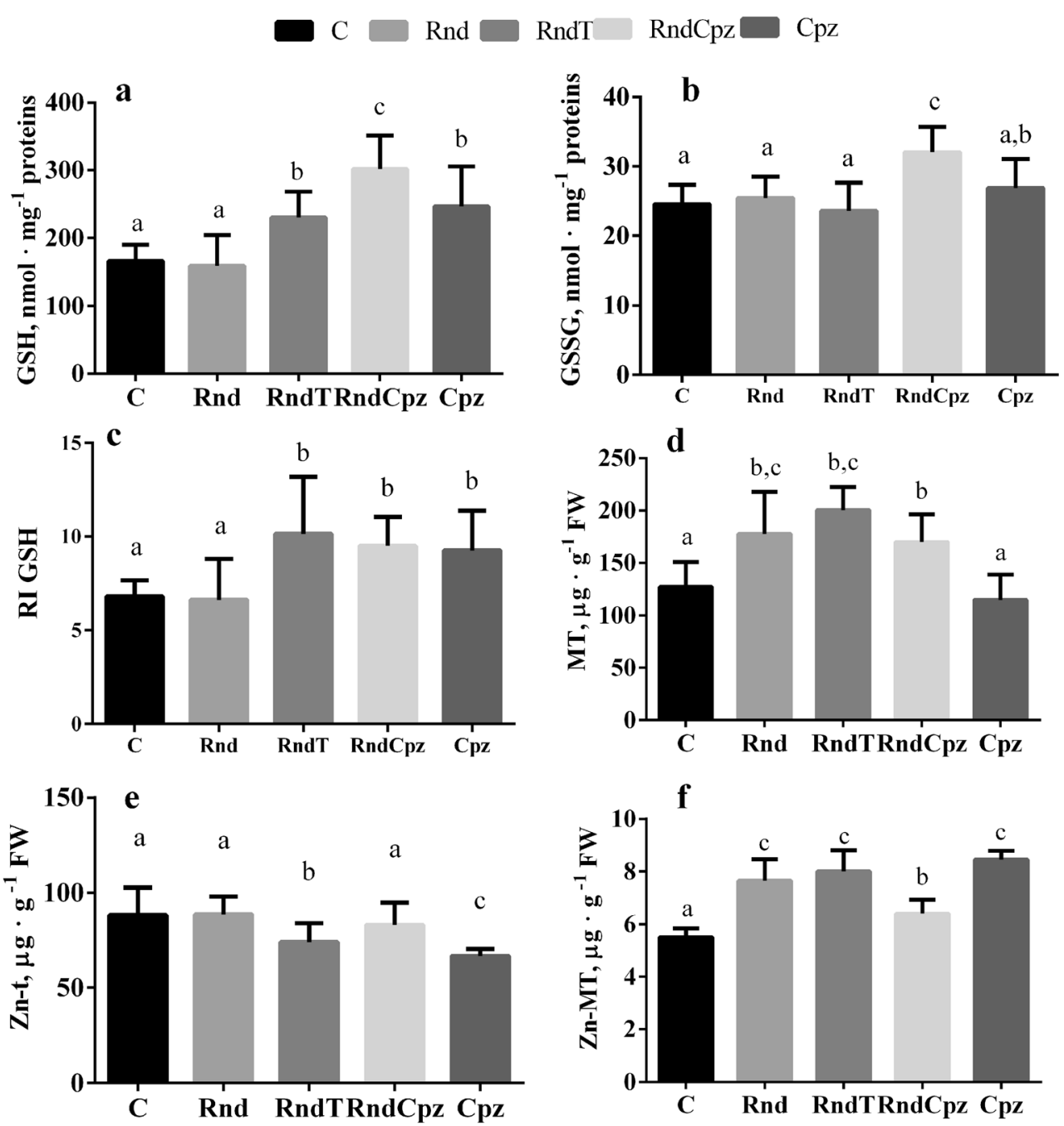




\section{Indexes of stress and toxicity}

The evaluation of oxidative stress responses indicated a substantial activation of the TAC by $23.4-51.3 \%$ in all exposures (Fig. 2a). The level of protein oxidation products (PC) increased compared to the control condition in all exposures except the Rnd-group (Fig. 2b). The highest increase was recorded in RndT-group by $32.5 \%$.

The monooxygenase-related biotransformation function (CYP450) attested by the EROD activity was greatly enhanced by 2.4-3 times in all treated groups except the Rndgroup(Fig. 2c). The changes of GST activity compared to control occurred in single treatments, i.e., an increase by $26.2 \%$ in the Rnd-group and a decrease by $21.9 \%$ in the Cpz-group. In contrast, there were no changes in the joint treatments in the RndT- and RndCpz-groups (Fig. 2d).

For the indexes of toxicity, some differences were also found (Fig. 3). ChE activity increased compared to the control value in the Rnd-, RndCpz-, and Cpz-groups yet did not differ from the control value in the RndT-group (Fig. 3a). The lysosomal integrity decreased in the RndT-group, increased in the Cpz-group, and remained the same in the other groups (Fig. 3b).

The activity of the central executive enzyme of apoptosis, caspase-3, was substantially increased in the molluscs' exposures to $\mathrm{Rn}$ and $\mathrm{RnCpz}$ (by 36.4\%) and was not changed in other treatment groups (Fig. 3c). The metabolic intensity was indicated by the citrate synthase activity. It enhanced compared to control in all exposures, except the Rnd-group, particularly in the Cpz-related groups, by $36.5-43.0 \%$ (Fig 3d).

\section{Data integration}

The Pearson correlation analysis revealed multiple associations among the studied indices in U. tumidus across all experimental groups (Supplementary Table 1). The greatest number of correlations was found for the indexes of oxidative stress and GSH. In opposite, MT and NRR did not show any correlations with other indexes. The application of PCA to datasets to identify relations between indices (Fig. 4a) illustrated a good distribution of variables with a factor loading higher than $|0.37|$. The set of Zn-MT, TAC (ABTS*), PC, EROD, GSH, RI GSH, and CS belonged positively to the first principal component ( $\mathrm{PC} 1$ ), and $\mathrm{Zn}$-t located opposite. The set of caspase-3, ChE, and GST was positively related, and CS was related negatively to $\mathrm{PC} 2$ with factor loading higher than $|0.42|$. Generally, $53.6 \%$ of the variance was accounted for the first three factors.

According to canonical discriminant analysis, all specimens in the C-, RndCpz-, and Cpz-groups and 75\% of specimens in the Rnd- and RndT-groups were classified correctly. As shown in Fig. 4b, the C- and Rnd-groups jointly (group centroids -7.55 and -3.96 , respectively, Supplementary Table 2) were well separated in the space of discriminant variables along axis 1 compared to the oppositely located Cpz-group with the centroid value of 7.33. Subjected to combined exposures, the RndT- and RndCpz-groups were placed between these opposite positions along axis 1 and located similarly with centroids values of 2.97 and 2.51 along axis 2. Two-way ANOVA confirmed the significance of the interaction between the effect of Rnd and Cpz in the RndCpz-
Fig. 2 Oxidative stress and biotransformation parameters in the digestive gland of $U$. tumidus after 14 days of experimental exposures to Rnd (Rnd), Rnd and heating (RndT), Rnd and chlorpromazine (RndCpz), and chlorpromazine $(\mathrm{Cpz})$ during 14 days. a Total antioxidant (ABTS* radical scavenging) activity; $\mathbf{b}$ protein carbonyls production (PC); c7-EROD activity; and d GST activity. Data are presented as means \pm standard deviations ( $n$ $=8)$. Different letters above the columns indicate significantly different values $(P<0.05)$
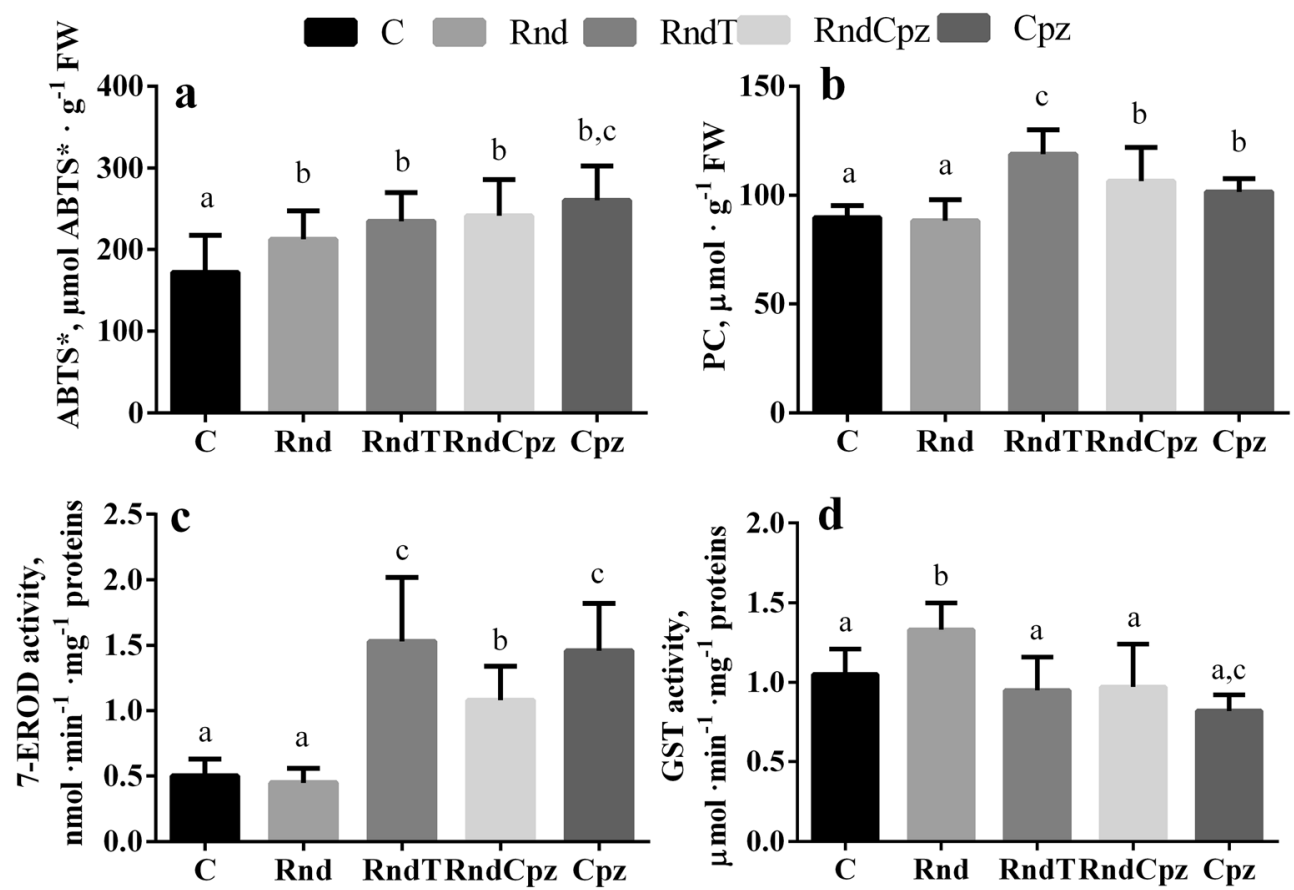
Fig. 3 Cytotoxicity and metabolism parameters in the digestive gland of $U$. tumidus exposed to Rnd (Rnd), Rnd and heating (RndT), Rnd and chlorpromazine (RndCpz), and chlorpromazine (Cpz) during 14 days. a Cholinesterase (ChE) activity; b lysosomal membrane stability (NRR); ccaspase-3 activity; and $\mathbf{d}$ citrate synthase (CS) activity. Data are presented as means \pm standard deviations $(n=$ 8). Different letters above the columns indicate significantly different values $(P<0.05)$

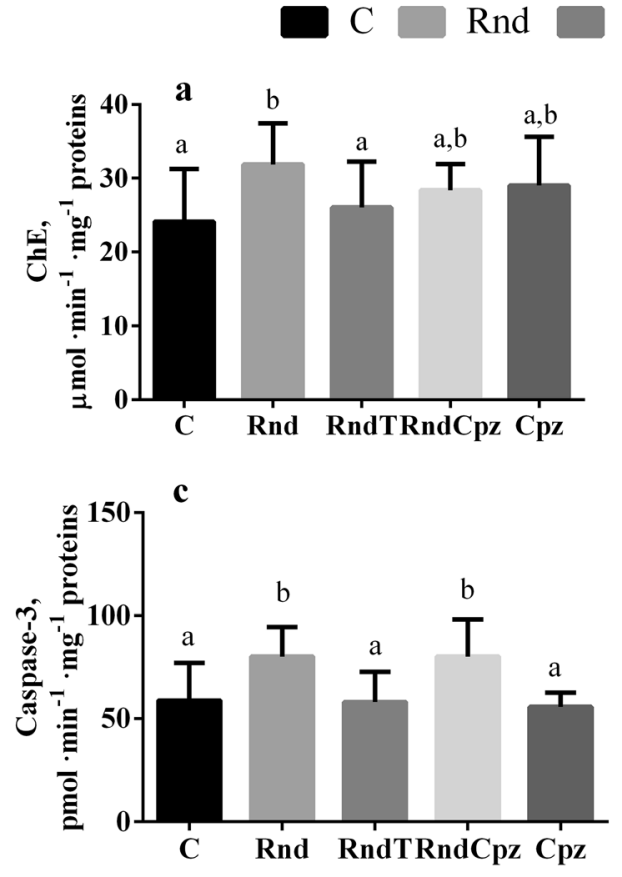

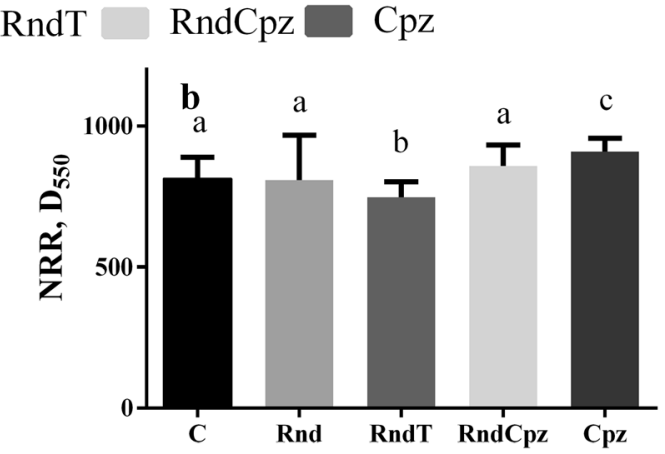

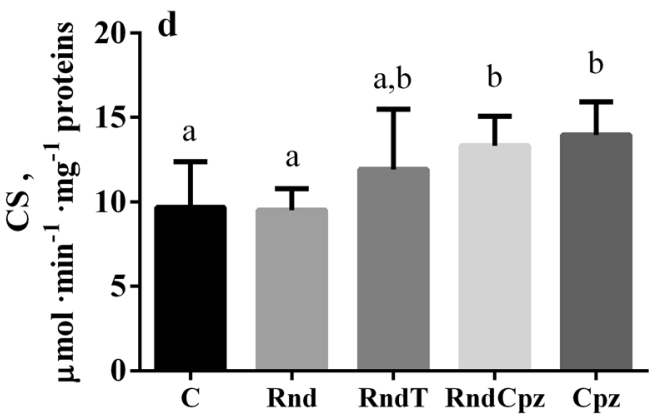

group (Supplementary Table 6). The effect of Cpz was demonstrated for the most studied indices except MTSH, caspase3 , and ChE $(P<.05)$, whereas an overall effect of Rnd was indicated for MTSH, Zt-t, GSSG, caspase-3, GST, and EROD. A Rnd $\times$ Cpz interaction was indicated for $\mathrm{Zn}-\mathrm{t}, \mathrm{Zn}-$ MT, and GSSG, only $(P<.05)$ (Supplementary Table 7).

The calculated values of IBR $/ \mathrm{n}$ in relation to baseline (control) value equaled $0.54,0.69,1.71$, and 1.84 , for the Rnd-, RndT-, RndCpz-, and Cpz-groups, respectively. The highest IBR/n values were observed in the RndCpz- and Cpz-groups, indicating a particular increase in the A values for most indexes (Fig. 5). The input of Zn-MT was the highest

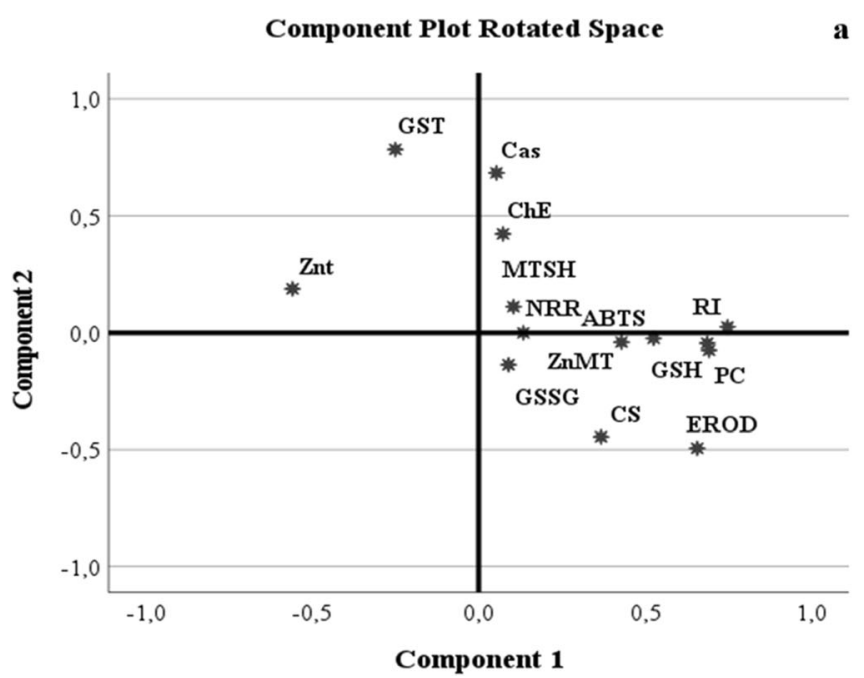

Fig. 4 The results of the principal component analysis applied to reveal the relations between measured parameters (a) and scatter plots of the canonical values on the first and second canonical discriminant axes to in all groups alike. The A values in the Cpz-group were opposite to other groups for plural indexes. On the other hand, the changes compared to control in the Rnd-group were lesser for all indices except Zn-MT and GSH.

\section{Discussion}

This study aimed to demonstrate whether the combined exposure could distort the specific responses of bivalve molluscs to aquatic pollutants at lower possible environmental concentrations. Discriminant analysis indicated the lesser distinction

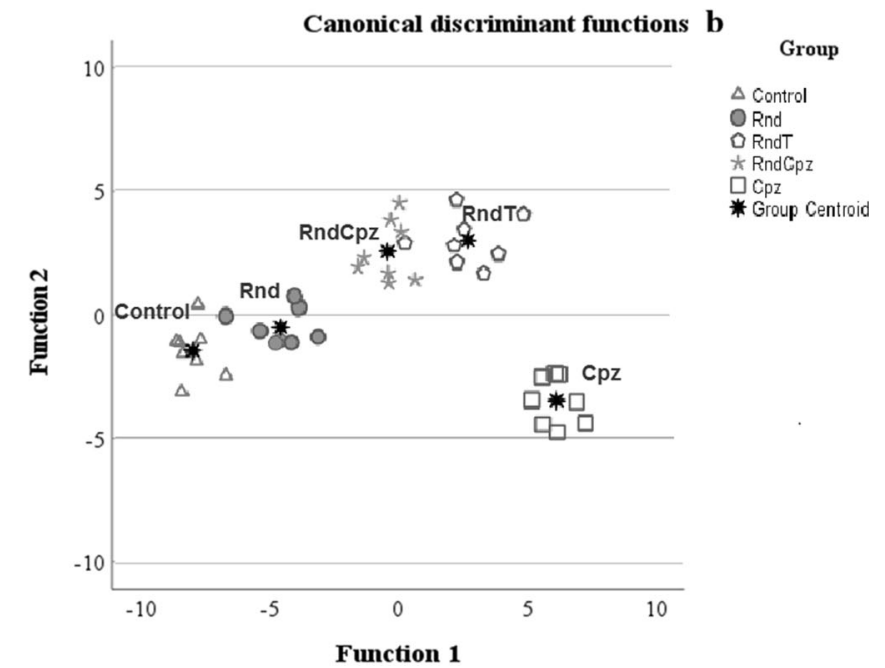

discriminate the groups of molluscs (b). a The abbreviations seen in the text. b Control group (1); groups exposed to Rnd (2), Rnd and heating (3), Rnd and chlorpromazine (4), and chlorpromazine (5) during 14 days 
Fig. 5 Biomarker star plots (Ai variables) of multiple biomarker responses of $U$. tumidus exposed to Rnd (Rn), Rnd and heating (RnT), Rnd and chlorpromazine (RnCpz), and chlorpromazine (Cpz) during 14 days compared to control values considered as zero values $(\mathrm{C})$

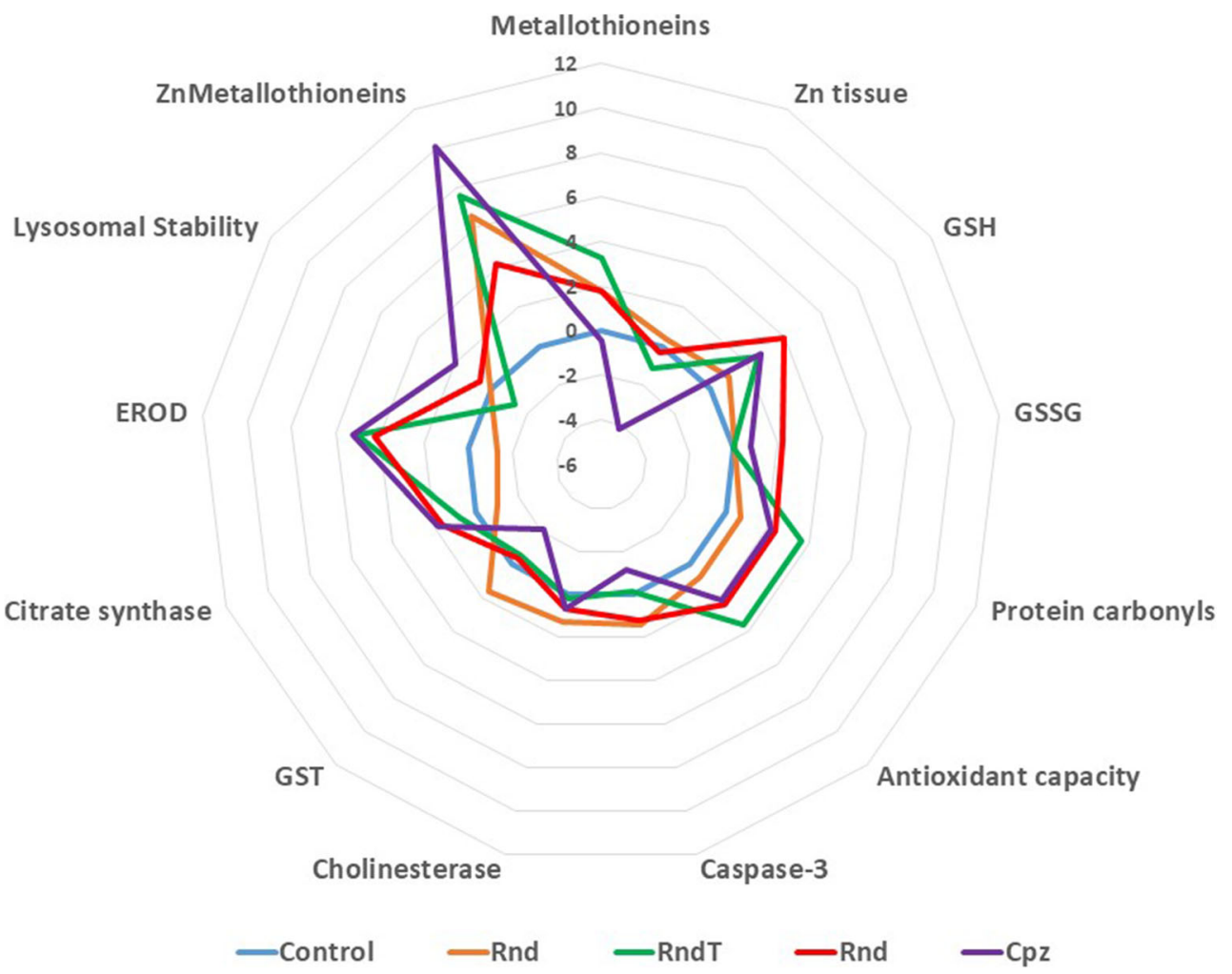

from control for Rnd-group, confirming the effect of concentration equalled 0.2 PNEC as almost negligible. The highest difference was detected for the Cpz-group (Figs. 4b and 5). Interestingly, the concerted exposures (RndT- and RndCpzgroups) produced similar integrative responses, distinct from each exposure to individual substance. However, a number of peculiar manifestations were indicated in each group.

\section{Is zinc metabolism in mollusc sensitive to low concentrations of Rnd and chlorpromazine?}

The involvement of $\mathrm{Zn}$ in cellular defense and regulation appears to be the common mechanism that can determine the resistance to adverse impacts. Various xenobiotics and physicochemical factors have been reported to result in the impairment of $\mathrm{Zn}$ metabolism and, subsequently, Zn deficiency in animals (Krężel and Maret 2016). As discussed in relation to several organisms, Rnd can chelate metals and cause their imbalance (Tsui et al. 2005; De Liz Oliveira Cavalli et al. 2013; Mertens et al. 2018). Both Rnd and Cpz can affect Zn functionality indirectly via $\mathrm{Ca}$-depending processes, whereas the cellular entry of $\mathrm{Zn}$ can be realized through several types of Ca-permeable channels (Bouron and Oberwinkler 2013; Hamaguchi et al. 2014). Particularly, Rnd and glyphosate selectively influence L-type $\mathrm{Ca}$ channels and their genes in the exposures of rat testis or isolated Sertoli cells and zebrafish embryos (De Liz Oliveira Cavalli et al. 2013; Gaur and
Bhargava 2019). Cpz also influences many Ca-dependent processes (Xu et al. 2010; Hamaguchi et al. 2014).

In our study, we found a decrease in the $\mathrm{Zn}$ uptake in the RndT- and Cpz-groups (Fig. 1a, a), yet Rnd per se did not change Zn-t. Importantly, at a twice higher concentration than used in this study, Rnd also decreased the Zn-t level in the digestive gland of $U$. tumidus only in the mixture at elevated temperature (Khoma et al. 2021). Similarly, distortion of the response to Rnd by warming was shown by Amid et al. (2018) in the tropical staghorn coral Acropora formosa. The specificity of the effect of $\mathrm{Cpz}$ on molluscs was supported by the presence of a dopamine $\mathrm{D}_{1}$-like receptor in the albumen gland of air-breathing freshwater snail Helisoma duryi (Planorbidae) (Mukai et al. 2004). Nevertheless, this effect of Cpz was abolished in the complex exposure of $U$. tumidus to Rnd and $\mathrm{Cpz}$. The significant interaction of the effects of Rnd and $\mathrm{Cpz}$ in the RndCpz-group was based on the Zn-related indexes, namely, Zn accumulation in the tissue and MT and GSSG, involved in the $\mathrm{Zn}$ transfer (Supplementary Tables 6 and 7). Thus, we confirm the sensitivity of $\mathrm{Zn}$ metabolism in the mollusc to Rnd, Cpz, and their combination in the environmentally relevant concentrations and combinations, although in the case of Rnd under heating only.

The elevated accumulation of Zn in MTs was a shared manifestation (Fig. 1f). MT played a critical role in Zn homeostasis under various conditions, but $\mathrm{Zn}$ chelating in the thiolate clusters of MT depended on the redox state of thiols (Krężel and Maret 2016). The adverse effects of different nature 
decreased the level of labile $\mathrm{Zn}$ and metalation of MT in molluscs even when the total level of this protein was increased (Khoma et al. 2021). In the present study, the elevation of ZnMT was well-coordinated with the TAC and GSH responses (Fig. 4a). Consequently, this common response indicated the enhancement of antioxidant activity and redox state of thiols. In opposite, the loss of MT metalation was frequently accompanied by plural signs of toxicity. For example, in the exposure to $33.6 \mu \mathrm{g} / \mathrm{L}$ of Rnd, the depletion of Zn-MT was accompanied by the decrease of the ChE and GST activities, lysosomal integrity, and increase in the GSSG level (Khoma et al. 2021). In the present study, the signs of toxicity were almost absent. This attested to the low molecular weight thiols as the successful biochemical drivers that provided the redox power in the exposures of low-level toxicity.

\section{Enzymes of biotransformation as the probable targets for Rnd and chlorpromazine}

Data concerning the biotransformation of Rnd and $\mathrm{Cpz}$ by the enzymes of phases I and II are scant and contradictory. Phosphonate-based pesticide formulations are known to cause a reduction in CYP450 enzyme levels in mammals (Mesnage and Antoniou 2017). However, studies show that the exposure of rats to Rnd in drinking water causes a decrease of EROD activity in male specimens while causing an increase in the female specimens (Larsen et al. 2014). Concerning Cpz, only a small number of studies have been designed to investigate the environmental fate of any tricyclic antipsychotic drug (Trautwein and Kümmerer 2012). Cpz is classified as nonbiodegradable in all of the biodegradation tests with aquatic bacteria (Trautwein and Kümmerer 2012; Jiménez et al. 2016). However, its biotransformation products have been elucidated by multiple-stage mass spectrometry (Trautwein and Kümmerer 2012). In the present study, the increase of EROD activity was not a specific Cpz feature. The strong correlation between EROD and a set of indices of antioxidant and metabolic activities and Zn-MT attested to this increase as a part of a well-coordinated, probably hermetic-like defensive response to low concentrations of xenobiotics (Fig. 4a).

The GST activity did not correlate with EROD in this and other studies on aquatic animals from polluted areas or on aquatic animals exposed to several substances (Domingues et al. 2010). The decrease or absence of GST response was reported in the exposures of molluscs to higher Rnd or glyphosate concentrations (Matozzo et al. 2019; Khoma et al. 2021). In the present study, GST activation could be explained by the low-strength Rn impact. GST activation was also indicated in the testes of rats exposed to Rn (De Liz Oliveira Cavalli et al. 2013). For Cpz, the decrease in GST activity was one of the most particular reactions observed in this study. The inhibition of GST was also illustrated for the effect of Cpz in vitro (Türkan et al. 2020). Moreover, among four tested drugs, Cpz was found to be the best inhibitor for the GST enzyme (Oliveira et al. 2015). Hence, the two manifestations confirmed in our study, Zn and GST levels' decrease, might be effect-specific for this drug. However, both of them were abolished in the combined RndCpz-exposure.

In the present study, the GST activity was coordinated with those of the ChE and caspase-3 (Figs. 3a, c and 4a). The responses of GST and ChE were frequently analyzed jointly as the prospective biomarkers in molluscs (Domingues et al. 2010). For the organophosphates' acute effect, the expected response was the depletion of $\mathrm{ChE}$ ( $\mathrm{Li}$ et al., 2018; Matozzo et al. 2019), whereas the upregulation of ChE in molluscs was seldom detected and discussed (Domingues et al. 2010). In this study, the upregulation of $\mathrm{ChE}$ might be a sign of the non-toxic level of exposure to Rnd, which was consistent with other manifestations in Rnd-group. In the vertebrates, the simultaneous increase in $\mathrm{ChE}$ and caspase- 3 activities was indicated (Hu et al. 2009), and $\mathrm{ChE}$ was proposed as a marker for apoptosis (Zhang and Greenberg 2012). This common regularity was detected for the neurons of insect Locusta migratoria, where the addition of $\mathrm{ChE}$ inhibitors reduced apoptotic cell death (Knorr et al. 2020). In freshwater mussels Unionidae, simultaneous increase of $\mathrm{ChE}$ and caspase-3 activities was indicated under the effect of pesticides, pharmaceuticals, and heating (Khoma et al. 2021). Nevertheless, the common regularity in the alterations of GST, ChE, and caspase- 3 cannot be explained unambiguously based on the current study data. Hence, we found that an EROD activation was a constituent of the common, probably hermetic-like, stress response, while the set of GST, ChE, and caspase-3 activities was more exposure-specific.

\section{How can we attest to the severity of injury?}

The analysis of each studied biomarker confirmed that we used low enough concentrations of xenobiotics, which did not provoke obvious toxicity. The mobilization of antioxidants and alterations of metabolic activity corresponded to a low-dose stimulation (Lefcort et al. 2008). This kind of response was evident from TAC and CS activation. A significant but not a prominent increase of protein carbonylation might be regarded as the triggering signal for antioxidant enhancement. Similarly, the EROD activation could induce antioxidants (He et al. 2017). Particularly, low-weight thiols seemed to be of decisive importance. High intercorrelations were shown in the set of TAC (ABTS*), Zn-MT, GSH, RI GSH, CS, and EROD (Fig. 4a).

GSH is on the first line of antioxidant defense as a radical scavenger. Plural examples show the involvement of GSH in the antioxidant activity in bivalve molluscs (Regoli et al. 2011; Gnatyshyna et al. 2020; Khoma et al. 2021). In these examples and precisely under the exposures to Rnd at different models, the responses of GSH\&GSSG are highly different 
(Larsen et al. 2014; Melo Tarouco et al. 2017) depending on the severity of impact. In any case, GSH and MTSH (last except $\mathrm{Cpz}$-group) activation can support the redox balance and provide the $\mathrm{Zn}$ chelating in the present study's model exposures.

In this study, the joint exposure to Rnd and heating might be qualified as the most disturbing. Only in this group, the lysosomal integrity was decreased. A similar phenomenon was previously observed at higher concentrations of mixture which included Rnd and heating (Khoma et al. 2021). The loss of the lysosomal integrity was an approved sign of toxicity and thermal stress in molluscs (Negri et al. 2013; Izagirre et al. 2014; Koagouw and Ciocan 2018). However, the opposite effect on lysosome integrity was indicated in the $\mathrm{Cpz}$-group. This unusual effect was also observed for the Ca channel blocker nifedipine (Khoma et al. 2021). Both these pharmaceuticals would be involved in the Ca-related functions of lysosomes, explaining the similarity of the lysosomal manifestation. As shown before, the $\mathrm{pH}$ homeostasis in lysosomes/ late endosomes was rather stable in the presence of cationic amphiphilic drugs and strictly maintained even after a longer treatment with Cpz (Hamaguchi et al. 2014).

Generally, the calculated IBR-indices provided the opportunity to analyze both specific and common traits of responses and to detect their severity (Fig. 5).

\section{Conclusions}

The applied low subchronic exposures to common aquatic pollutants allowed us to highlight the mobilization of antioxidant and metabolic responses in bivalve molluscs with certain specificity in the Roundup- and chlorpromazine-exposed groups. Complex exposures abolished this specificity, and heating enhanced the toxicity of almost no-effect concentration of Roundup to molluscs. Discriminant analysis and IBR calculation of the battery of biomarkers highlighted the benefits of multi-marker expertise in identifying the strength of the response.

Supplementary Information The online version contains supplementary material available at https://doi.org/10.1007/s11356-021-16775-1.

Acknowledgements The authors are grateful to master students Yunko K., Formanchuk R., and Nikonchuk A. for the technical assistance.

Author contribution Oksana Stoliar contributed to the conception and design, acquisition, analysis, and interpretation, drafted the manuscript, and gave final approval. Levonas Manusadžianas contributed to the conception and design, critically revised the manuscript, and gave final approval. Lesya Gnatyshyna contributed to design, analysis, and interpretation and gave final approval; Vira Khoma contributed to experimental analysis and statistic preparation and gave final approval; Viktoria Martinyuk contributed to sampling and analysis and gave final approval; Tetyana Matskiv contributed to analysis and draft preparation and gave final approval; Vitaliy Baranovsky contributed to statistic preparation and acquisition and gave final approval; Mykola Gladiuk contributed to sampling and draft preparation and gave final approval; Brigita Gylytė contributed to draft preparation and gave final approval.

Funding This work has been granted by the Ministry of Education and Science of Ukraine to Oksana Stoliar (Project 132B and UkrainianLithuanian R\&D Project No. M19/2020) and by the Research Council of Lithuania (Project No. S-LU-20-10 under the Lithuanian-Ukrainian Cooperation Program).

Data availability Methodology used in detail and all data analyzed during this study and statistical calculations are available via the Mendeley Data by the following link: https://doi.org/10.17632/365bfpzs4w.3.

\section{Declarations}

Ethics approval All applicable international, national, and/or institutional guidelines for the care and use of animals were followed.

Consent to participate Informed consent was obtained from all individual participants included in the study.

Consent for publication All authors have approved this version of the work.

Competing interests The authors declare no competing interests.

\section{References}

Alkimin GD, Nunes B, Soares AMVM, Bellot M, Gómez-Canela C, Barata C (2020)Daphnia magna responses to fish kairomone and chlorpromazine exposures. Chem Biol Interact 325:109123. https:// doi.org/10.1016/j.cbi.2020.109123

Amid C, Olstedt M, Gunnarsson JS, Le Lan H, Tran Thi Minh H, Van den Brink PJ, Hellström M, Tedengren M (2018) Additive effects of the herbicide glyphosate and elevated temperature on the branched coral Acropora formosa in Nha Trang, Vietnam. Environ Sci Pollut Res 25:13360-13372. https://doi.org/10.1007/s11356-016-8320-7

Baresel C, Palm Cousins A, Hörsing M, Ek M, Ejhed H, Allard AS, Magnér J, Westling K, Wahlberg C, Fortkamp U, Söhr S (2015) Pharmaceutical residues and other emerging substances in the effluent of sewage treatment plants. IVL Swedish Environmental Research Institute, Report B, 2226.

Bonansea RI, Filippi I, Wunderlin DA, Marino DJ, Amé MV (2018) The fate of glyphosate and AMPA in a freshwater endorheic basin: an ecotoxicological risk assessment. Toxics 6:3. https://doi.org/10. 3390/toxics6010003

Bouron A, Oberwinkler J (2013) Contribution of calcium-conducting channels to the transport of zinc ions. Pflugers Arch 466:381-387. https://doi.org/10.1007/s00424-013-1295-z

Carles L, Gardon H, Joseph L, Sanchís J, Farre M, Artigas J (2019)Metaanalysis of glyphosate contamination in surface waters and dissipation by biofilms. Environment International 124:284-293. https:// doi.org/10.1016/j.envint.2018.12.064

De Liz Oliveira Cavalli VL, Cattani D, Heinz Rieg CE, Pierozan P, Zanatta L, Benedetti Parisotto E, Wilhelm Filho D, Mena Barreto Silva FR, Pessoa-Pureur R, Zamoner A (2013) Roundup disrupts 
male reproductive functions by triggering calcium-mediated cell death in rat testis and Sertoli cells. Free Radic Biol Med 65:335346. https://doi.org/10.1016/j.freeradbiomed.2013.06.043

Domingues I, Agra AR, Monaghan K, Soares AM, Nogueira AJ (2010) Cholinesterase and glutathione-S-transferase activities in freshwater invertebrates as biomarkers to assess pesticide contamination. Environ Toxicol Chem 29:5-18. https://doi.org/10.1002/etc.23

Ebi KL, Vanos J, Baldwin JW, Bell JE, Hondula DM, Errett NA, Hayes K, Reid CE, Saha S, Spector J, Berry P (2021) Extreme weather and climate change: population health and health system implications. Annu Rev Public Health 42:293-315. https://doi.org/10.1146/ annurev-publhealth-012420-105026

El Haj Y, Bohn S, Souza MM (2019) Tolerance of native and invasive bivalves under herbicide and metal contamination: an ex vivo approach. Environ Sci Pollut Res Int 26:31198-31206. https://doi.org/ 10.1007/s11356-019-06256-x

Ellman GL, Courtney KD, Andres VJ, Featherstone RM (1961) A new and rapid colorimetric determination of acetylcholinesterase activity. Biochem Pharmacol 7:88-90. https://doi.org/10.1016/00062952(61)90145-9

Flynn EE, Bjelde BE, Miller NA, Todgham AE (2015) Ocean acidification exerts negative effects during warming conditions in a developing Antarctic fish. Conserv Physiol 3:cov033. https://doi.org/10. 1093/conphys/cov033

Frédéric O, Yves P (2014) Pharmaceuticals in hospital wastewater: their ecotoxicity and contribution to the environmental hazard of the effluent. Chemosphere 115:31-39. https://doi.org/10.1016/j. chemosphere.2014.01.016

Gaur H, Bhargava A (2019) Glyphosate induces toxicity and modulates calcium and NO signaling in zebrafish embryos. Biochem Biophys Res Commun 513(4):1070-1075. https://doi.org/10.1016/j.bbrc. 2019.04.074

Giménez V, Nunes B (2019) Effects of commonly used therapeutic drugs, paracetamol, and acetylsalicylic acid, on key physiological traits of the sea snail Gibbula umbilicalis. Environ Sci Pollut Res 26: 21858-21870. https://doi.org/10.1007/s11356-019-04653-w

Gnatyshyna L, Khoma V, Mishchuk O, Martinyuk V, Sprinğe G, Stoliar O (2020)Multi-marker study of the responses of the Unio tumidus from the areas of small and micro hydropower plants at the Dniester River Basin, Ukraine. Environ Sci Pollut Res 27:11038-11049. https://doi.org/10.1007/s11356-020-07698-4

Griffith OW (1980) Determination of glutathione and glutathione disulfide using glutathione reductase and 2-vinylpyridine. Anal Biochem 106(1):207-212. https://doi.org/10.1016/0003-2697(80)90139-6

Habig WH, Pabst MJ, Jakoby WB (1974) Glutathione S-transferases. The first enzymatic step in mercapturic acid formation. J Biol Chem 249: 7130-7139

Hamaguchi R, Haginaka J, Tanimoto T, Kuroda Y (2014) Maintenance of luminal $\mathrm{pH}$ and protease activity in lysosomes/late endosomes by vacuolar ATPase in chlorpromazine-treated RAW264 cells accumulating phospholipids. Cell Biol Toxicol 30:67-77. https://doi.org/10. 1007/s10565-014-9269-2

Hansen LR, Roslev P (2016) Behavioral responses of juvenile Daphnia magna after exposure to glyphosate and glyphosate-copper complexes. Aquat Toxicol 179:36-43. https://doi.org/10.1016/j. aquatox.2016.08.010

He L, HeT FS, Ji L, Liu T, Ma X (2017) Antioxidants maintain cellular redox homeostasis by elimination of reactive oxygen species. Cell Physiol Biochem 44:532-553. https://doi.org/10.1159/000485089

Hong E-M, Pachepsky YA, Whelan G, Nicholson T (2017) Simpler models in environmental studies and predictions. Critical Reviews in Environmental Science and Technology 47:1669-1712. https:// doi.org/10.1080/10643389.2017.1393264

Hu T, Fu Q, Liu X, Zhang H, Dong M (2009) Increased acetylcholinesterase and caspase- 3 expression in the brain and peripheral immune system of focal cerebral ischemic rats. J Neuroimmunol 211:84-91. https://doi.org/10.1016/j.jneuroim.2009.04.002

Izagirre U, Errasti A, Bilbao E, Múgica M, Marigómez I (2014) Combined effects of thermal stress and $\mathrm{Cd}$ on lysosomal biomarkers and transcription of genes encoding lysosomal enzymes and HSP70 in mussels, Mytilus galloprovincialis. Aquat Toxicol 149:145-156. https://doi.org/10.1016/j.aquatox.2014.01.013

Jiménez JJ, Muñoz BE, Sánchez MI, Pardo R, Vega MS (2016) Fate of the drug chlorpromazine in river water according to laboratory assays. Identification and evolution over time of degradation products. Sorption to sediment. Chemosphere 162:285-292. https://doi.org/ 10.1016/j.chemosphere.2016.07.107

Khoma VV, Gnatyshyna LL, Martinyuk VV, Mackiv TR, Mishchuk NY, Stoliar O (2020) Metallothioneins contribution to the response of bivalve mollusk to xenobiotics. Ukr Biochem J 92:87-96. https:// doi.org/10.15407/ubj92.05.087

Khoma V, Gnatyshyna L, Martinyuk V, Mackiv T, Mishchenko L, Manusadžianas L, Stoliar O (2021) Common and particular biochemical responses of Unio tumidus to herbicide, pharmaceuticals and their combined exposure with heating. Ecotoxicol Environ Saf 208:111695. https://doi.org/10.1016/j.ecoenv.2020.111695

Klotz AV, Stegeman JJ, Walsh C (1984) An alternative 7ethoxyresorufin O-deethylase activity assay: a continuous visible spectrophotometric method for measurement of cytochrome P-450 monooxygenase activity. Anal Biochem 140:138-145. https://doi. org/10.1016/0003-2697(84)90144-1

Knorr DY, Georges NS, Pauls S, Heinrich R (2020) Acetylcholinesterase promotes apoptosis in insect neurons. Apoptosis 25:730-746. https://doi.org/10.1007/s10495-020-01630-4

Koagouw W, Ciocan C (2018) Impact of metformin and increased temperature on blue mussels Mytilus edulis- evidence for synergism. J Shellfish Res 37(3):467-474. https://doi.org/10.2983/035.037.0301

Krężel A, Maret W (2016) The biological inorganic chemistry of zinc ions. Arch Biochem Biophys 611:3-19. https://doi.org/10.1016/j. abb.2016.04.010

Larsen K, Najle R, Lifschitz A, Maté ML, Lanusse C, Virkel GL (2014) Effects of sublethal exposure to a glyphosate-based herbicide formulation on metabolic activities of different xenobioticmetabolizing enzymes in rats. Int J Toxicol 33:307-318. https:// doi.org/10.1177/1091581814540481

Lefcort H, Freedman Z, House S et al (2008) Hormetic effects of heavy metals in aquatic snails: is a little bit of pollution good? EcoHealth 5(1):10-17. https://doi.org/10.1007/s10393-008-0158-0

Li P, Snyder GL, Vanover KE (2016) Dopamine targeting drugs for the treatment of schizophrenia: past, present and future. Curr Top Med Chem 16:3385-3403. https://doi.org/10.2174/ 1568026616666160608084834

Liu N, Zhong G, Zhou J, Liu Y, Pang Y, Cai H, Wu Z (2019) Separate and combined effects of glyphosate and copper on growth and antioxidative enzymes in Salvinia natans (L.) All. Sci Total Environ. 655:1448-1456. https://doi.org/10.1016/j.scitotenv.2018.11.213

Louis F, Rocher B, Barjhoux I, Bultelle F, Dedourge-Geffard O, Gaillet V, Bonnard I, Delahaut L, Pain-Devin S, Geffard A, Paris-Palacios S, David E (2020) Seasonal monitoring of cellular energy metabolism in a sentinel species, Dreissena polymorpha (bivalve): effect of global change? Sci Total Environ 725:138450. https://doi.org/10. 1016/j.scitotenv.2020.138450

Lowry OH, Rosebroungh HJ, Farr AL, Randall RJ (1951) Protein measurement with folin phenol reagent. J Biol Chem 193:265-275. https://doi.org/10.1016/S0021-9258(19)52451-6

Martin OV, Adams J, Beasley A, Belanger S, Breton RL, Brock TCM, Buonsante VA, Galay Burgos M, Green J, Guiney PD, Hall T, Hanson M, Harris MJ, Henry TR, Huggett D, Junghans M, Laskowski R, Maack G, Moermond CTA et al (2019) Improving environmental risk assessments of chemicals: steps towards 
evidence-based ecotoxicology. Environ Int 128:210-217. https:// doi.org/10.1016/j.envint.2019.04.053

Matozzo V, Munari M, Masiero L, Finos L, Marin MG (2019) Ecotoxicological hazard of a mixture of glyphosate and aminomethylphosphonic acid to the mussel Mytilus galloprovincialis (Lamarck 1819). Sci Rep 9:14302. https://doi. org/10.1038/s41598-019-50607-0

Matozzo V, Fabrello J, Marin MG (2020) The effects of glyphosate and its commercial formulations to marine invertebrates: a review. J Mar Sci Eng 8:399. https://doi.org/10.3390/jmse8060399

Maycock D, Crane M, Atkinson C, Johnson J (2012) Proposed EQS for water framework directive annex VIII substances: glyphosate (for consultation). Water Framework Directive - United Kingdom Technical Advisory Group (WFD-UKTAG). Sniffer, Edinburgh, 121 pp. https://www.wfduk.org/sites/default/files/Media/ Glyphosate\%20-\%20UKTAG.pdf. Accessed February 2021

Melo Tarouco F, De Godoi FGA, Velasques RR, Da Silveira GA, Geihs MA, Da Rosa CE (2017) Effects of the herbicide Roundup on the polychaeta Laeonereis acuta: cholinesterases and oxidative stress. Ecotoxicol Environ Saf 135:259-266. https://doi.org/10.1016/j. ecoenv.2016.10.014

Mertens M, Höss S, Neumann G, Afzal J, Reichenbecher W (2018) Glyphosate, a chelating agent - relevant for ecological risk assessment? Environ Sci Pollut Res 25:5298-5317. https://doi.org/10. 1007/s11356-017-1080-1

Mesnage R, Antoniou MN (2017) Facts and fallacies in the debate on glyphosate toxicity. Front Public Health 5:316. https://doi.org/10. 3389/fpubh.2017.00316

Miller TH, Ng KT, Bury ST, Bury SE, Bury NR, Barron LP (2019) Biomonitoring of pesticides, pharmaceuticals and illicit drugs in a freshwater invertebrate to estimate toxic or effect pressure. Environ Int 129:595-606. https://doi.org/10.1016/j.envint.2019.04.038

Mukai ST, Kiehn L, Saleuddin ASM (2004) Dopamine stimulates snail albumen gland glycoprotein secretion through the activation of a D1-like receptor. J Exp Biol 207:2507-2518. https://doi.org/10. 1242/jeb.01052

Negri A, Oliveri C, Sforzini S, Mignione F, Viarengo A, Banni M (2013) Transcriptional response of the mussel Mytilus galloprovincialis (Lam.) following exposure to heat stress and copper. PLoS One 8: e66802. https://doi.org/10.1371/journal.pone.0066802

Nelson M, Adams T, Ojo C, Carroll MA, Catapane EJ (2018) Manganese toxicity is targeting an early step in the dopamine signal transduction pathway that controls lateral cilia activity in the bivalve mollusc Crassostrea virginica. Comp Biochem Physiol C Toxicol Pharmacol 213:1-6. https://doi.org/10.1016/j.cbpc.2018.07.002

Oliveira LLD, Antunes SC, Gonçalves F, Rocha O, Nunes B (2015) Evaluation of ecotoxicological effects of drugs on Daphnia magna using different enzymatic biomarkers. Ecotoxicol Environ Saf 119: 123-131. https://doi.org/10.1016/j.ecoenv.2015.04.028

Patra RW, Chapman JC, Lim RP, Gehrke PC, Sunderam RM (2015) Interactions between water temperature and contaminant toxicity to freshwater fish. Environ Toxicol Chem. 34:1809-1817. https:// doi.org/10.1002/etc. 2990

Payton SL, Johnson PD, Jenny MJ (2016) Comparative physiological, biochemical and molecular thermal stress response profiles for two unionid freshwater mussel species. J Exp Biol 219(Pt 22):35623574. https://doi.org/10.1242/jeb.140129

Plaze M, Attali D, Petit AC, Blatzer M, Simon-Loriere E, Vinckier F, Cachia A, Chrétien F, Gaillard R (2020) Repurposing chlorpromazine to treat COVID-19: the reCoVery study. L'Encéphale 46:169172. https://doi.org/10.1016/j.encep.2020.05.006

Re R, Pellegrini N, Proteggente A, Pannala A, Yang M, Rice-Evans C (1999) Antioxidant activity applying an improved ABTS radical cation decolorization assay. Free Radic Biol Med 26:1231-1237. https://doi.org/10.1016/S0891-5849(98)00315-3

Regoli F, Benedetti M, Giuliani ME (2011) Antioxidant defenses and acquisition of tolerance to chemical stress. In: Amiard-Triquet C, Rainbow PS, Romeo M (eds) Tolerance to Environmental Contaminants, 1st edn. CRC Press, Boca Raton, pp 153-173. https://doi.org/10.1201/b10519-9

Reznick AZ, Packer L (1994) Oxidative damage to proteins: spectrophotometric method for carbonyl assay. Meth Enzymol 233:357-363. https://doi.org/10.1016/s0076-6879(94)33041-7

Roesijadi G, Fowler B (1991) Purification of invertebrate metallothioneins. Meth Enzymol 205B:263-273. https://doi.org/ 10.1016/0076-6879(91)05106-6

Skark C, Zullei-Seibert N, Schottler U, Schlett C (1998) The occurrence of glyphosate in surface water. Int J Environ Anal Chem 70:93-104. https://doi.org/10.1080/03067319808032607

Stip E, Rizvi TA, Mustafa F, Javaid S, Aburuz S, Ahmed NN, Abdel Aziz K, Arnone D, Subbarayan A, Al Mugaddam F, Khan G (2020) The large action of chlorpromazine: translational and transdisciplinary considerations in the face of COVID-19. Front Pharmacol 11: 577678. https://doi.org/10.3389/fphar.2020.577678

Trautwein C, Kümmerer K (2012) Degradation of the tricyclic antipsychotic drug chlorpromazine under environmental conditions, identification of its main aquatic biotic and abiotic transformation products by LC-MSn and their effects on environmental bacteria. J Chromatogr B 889-890:24-38. https://doi.org/10.1016/j.jchromb. 2012.01.022

Tsui MTK, Wang WX, Chu LM (2005) Influence of glyphosate and its formulation (Roundup ${ }^{\circledR}$ ) on the toxicity and bioavailability of metals to Ceriodaphnia dubia. Environ Pollut 138:59-68. https:// doi.org/10.1016/j.envpol.2005.02.018

Türkan F, Calimli MH, Kanberoğlu GS, Karaman M (2020) Inhibition effects of isoproterenol, chlorpromazine, carbamazepine, tamoxifen drugs on glutathione S-transferase, cholinesterases enzymes and molecular docking studies. J Biomol Struct Dyn 39(9):3277-3284. https://doi.org/10.1080/07391102.2020.1763200

Viarengo A, Ponzano E, Dondero F, Fabbri R (1997) A simple spectrophotometric method for metallothionein evaluation in marine organisms: an application to Mediterranean and Antarctic molluscs. Mar Environ Res 44:69-84. https://doi.org/10.1016/S0141-1136(96) 00103-1

Wang J, Niu Y, Zhang C, Chen Y (2018) A micro-plate colorimetric assay for rapid determination of trace zinc in animal feed, pet food and drinking water by ion masking nd statistical partitioning correction. Food Chem 245:337-345. https://doi.org/10.1016/j.foodchem. 2017.10.054

Xu B, Xu ZF, Deng Y, Yang JH (2010) Protective effects of chlorpromazine and verapamil against cadmium-induced kidney damage in vivo. Exp Toxicol Pathol 62:27-34. https://doi.org/10.1016/j. etp.2008.12.009

Yang JL, Li YF, Bao WY, Satuito CG, Kitamura H (2011) Larval metamorphosis of the mussel Mytilus galloprovincialis Lamarck, 1819 in response to neurotransmitter blockers and tetraethylammonium. Biofouling 27:193-199. https://doi.org/10.1080/08927014.2011. 553717

Zhang X-J, Greenberg DS (2012) Acetylcholinesterase involvement in apoptosis. Front Mol Neurosci 5:40. https://doi.org/10.3389/fnmol. 2012.00040https://ukr.seatemperature.net/seas-and-rivers/rekadnestr

Publisher's note Springer Nature remains neutral with regard to jurisdictional claims in published maps and institutional affiliations. 